\title{
Morphometric characters and their relationship in estuarine catfish
}

\author{
M. Begum, Abdullah-Al Mamun, M.L. Islam and M.J. Alam \\ Bangladesh Fisheries Research Institute, Brackishwater Station, Paikgacha, Khulna-9280
}

\begin{abstract}
The morphometric observations were made on total length, standard length, pre-caudal length, head length, eye diameter and depth of body at pectoral fin base of estuarine catfish $M$. gulio. Males and females showed homogeneity in characters. A linear relationship was found between total length and morphometric characters. Regression of length and weight did not deviate significantly from cube law indicating isometric growth. The fish exhibited sexual dimorphism.
\end{abstract}

Keywords: Morphometric characters, Estuarine catfish, Mystus gulio

\section{Introduction}

Mystus gulio (Ham.), popularly known as 'Nuna tengra' in Bangladesh, is an important commercial catfish of south western part and contributes a major share in catch composition of catfishes. Nowadays, estuarine catfish is being cultured in many ghers in the south west part of Bangladesh as an important source of quality food for the ever increasing human population. Recently Bangladesh Fisheries Research Institute introduced the artificial breeding techniques of the species suitable for the country. This species is dominant in the commercial catches during winter season (November to February). High landing in monsoon season is related to the gher dewatering. Earlier attempts to study the fishery, food and feeding, breeding, maturity, fecundity and length weight relationship of Mystus gulio were made by Alam et al. (2006a, 2006b) and Begum et al. (2007). Body measurements and their proportions are extensively used in identification of this species. Significant study and statistical relationship between the measurements of different body parts of fishes have been recognized in all taxonomic and systematic studies. Hence, the present study was undertaken to reckon the relationship between the various morphological body parts of estuarine catfish and to establish mathematical equations relating to the various morphometric relationships which could be utilized for the conversion of one measurement into another. The present study is an effort also to investigate the probable variations in males and females of the species. The rate of growth of different morphological body parts of the fish in relation to its total length was studied.

\section{Materials and Methods}

A total of 155 specimen of Mystus gulio (Males-90, Females-65) ranging from $85 \mathrm{~mm}$ to 216 $\mathrm{mm}$ were collected from pond complex of Brackishwater Station of Bangladesh Fisheries Research Institute, Paikgacha, Khulna. The specimens were classified according to sex. Total length $(T L)$, standard length (SL), pre-caudal length $(P C L)$, head length $(H L)$, eye diameter (ED) and body depth at pectoral fin base (BD) of the fish were measured to the nearest $\mathrm{mm}$ using fish measuring board. Measurements of depth of body were taken with the help of divider and calipers. The fishes were weighed on tanetag, KD-160 balance having one gm precision. The body characters viz. SL, PCL, BD, HL, etc. were expressed as percent to total length of the fish as done by Carlender and Smith (1954) and Hile (1948). Regression of various body parts against TL of the fish were drawn by least square method. Lengthweight relationship was calculated by cube law as given by Le Cren (1951). 
$\log \mathrm{W}=\log \mathrm{a}+\mathrm{n} \log \mathrm{L}$

Where, $W$ is weight, $L$ is length of fish and ' $a$ ' and ' $n$ ' are constants.

Regression of morphometric characters were compared between males and females by (Snedecor, 1956).

\section{Results and Discussion}

The PCL, SL were calculated as 85.23 and $79.04 \%$ of the total length of female fish respectively. The HL, ED and BD were found to be $17.27,14.77$ and $2.73 \%$ of the total length of the fish respectively. Fig. 1 shows a linear relationship between TL and various morphometric characters of the fish. The SL and PCL were calculated as 78.35 and $84.85 \%$ respectively of the total length of male fish. The HL, BD and ED were found to be 16.29 , 13.64 and $2.79 \%$ respectively of the total length of the fish.

Table 1. Morphometric measurements and rate of growth of different body parts in relation to the total length on a percentage basis of estuarine catfish Mystus gulio (in mm)

\begin{tabular}{|c|c|c|c|c|c|c|c|c|c|c|c|}
\hline \multirow{2}{*}{$\begin{array}{c}\mathrm{TL} \\
\text { Group } \\
(20 \mathrm{~mm})\end{array}$} & \multirow{2}{*}{$\begin{array}{l}\text { No. of } \\
\text { fish }\end{array}$} & \multicolumn{10}{|c|}{ Average } \\
\hline & & SL & PCL & $\mathrm{HL}$ & BD & ED & $\% S L$ & \%PCL & $\% \mathrm{HL}$ & $\% B D$ & \%ED \\
\hline 105 & 21 & 75.76 & 82.43 & 14.19 & 11.48 & 2.98 & 75.82 & 82.01 & 14.05 & 11.27 & 2.26 \\
\hline 125 & 28 & 92.93 & 101.39 & 18.79 & 15.21 & 3 & 76.94 & 83.63 & 15.68 & 12.67 & 2.42 \\
\hline 145 & 29 & 106.41 & 114.90 & 22.31 & 18.28 & 3.60 & 77.85 & 84.57 & 16.51 & 13.60 & 2.56 \\
\hline 165 & 45 & 122.24 & 131.13 & 26.89 & 23.13 & 4.04 & 79.22 & 85.38 & 17.38 & 14.95 & 2.88 \\
\hline 185 & 28 & 135.04 & 146.25 & 30.89 & 27.71 & 5.05 & 81.15 & 87.40 & 18.41 & 16.39 & 3.34 \\
\hline 205 & 3 & 149 & 158.67 & 35 & 30 & 6 & 85.96 & 92.01 & 19.32 & 17.63 & 3.99 \\
\hline 225 & 1 & 173 & 183 & 36 & 32 & 7 & 89.71 & 94.85 & 20 & 17.72 & 4.26 \\
\hline
\end{tabular}

$\mathrm{TL}=$ Total length, $\mathrm{SL}=$ Standard length, $\mathrm{PCL}=$ Pre-caudal length, $\mathrm{HL}=$ Head length, $\mathrm{BD}=$ Body depth, $\mathrm{ED}=$ Eye diameter

Table 2. Analysis of regression of body measurements of estuarine catfish Mystus gulio

\begin{tabular}{|c|c|c|c|c|c|c|}
\hline \multirow{2}{*}{$\begin{array}{l}\text { Body } \\
\text { parts }\end{array}$} & \multicolumn{3}{|c|}{ Residual } & \multicolumn{2}{|c|}{ Variations due to deviation from individual regression } & \multirow{2}{*}{$\begin{array}{c}\text { Calculated } \\
\text { "F" }\end{array}$} \\
\hline & DF & SS & MS & DF & MS & \\
\hline SL & 153 & 1580.469 & 10.32986 & 1 & 67343.82 & 6519.335 \\
\hline$\overline{P C L}$ & 153 & 1287.867 & 8.417433 & 1 & 75155.2 & 8928.519 \\
\hline $\mathrm{HL}$ & 153 & 427.8348 & 2.796306 & 1 & 4896.139 & 1750.931 \\
\hline$\overline{B D}$ & 153 & 822.4434 & 5.375447 & 1 & 4593.107 & 854.4604 \\
\hline$\overline{E D}$ & 153 & 52.58384 & 0.343685 & 1 & 58.95487 & 171.5374 \\
\hline
\end{tabular}

$\mathrm{DF}=$ Degree of freedom, $\mathrm{TL}=$ Total length, $\mathrm{SL}=$ Standard length, $\mathrm{PCL}=$ Pre-caudal length, $\mathrm{HL}=\mathrm{Head}$ length, $\mathrm{BD}=$ Body depth, $\mathrm{ED}=$ Eye diameter

Table 3. Regression equations for the estuarine catfish Mystus gulio (pooled)

\begin{tabular}{|l|c|c|c|c|c|}
\hline \multicolumn{5}{|c|}{ Regression equation } & Correlation coefficient \\
\hline $\mathrm{Y}=$ & $\mathrm{a}$ & + & $\mathrm{b}$ & $\mathrm{TL}$ & "r" \\
\hline $\mathrm{SL}=$ & 2.4193 & + & 0.7686 & $\mathrm{TL}$ & 0.9884 \\
\hline $\mathrm{PCL}=$ & 5.1809 & + & 0.8119 & $\mathrm{TL}$ & 0.9915 \\
\hline $\mathrm{HL}=$ & -5.4484 & + & 0.2072 & $\mathrm{TL}$ & 0.9589 \\
\hline $\mathrm{BD}=$ & -8.177 & + & 0.2007 & $\mathrm{TL}$ & 0.9209 \\
\hline $\mathrm{ED}=$ & 0.6597 & + & 0.0227 & $\mathrm{TL}$ & 0.7270 \\
\hline
\end{tabular}

$\mathrm{SL}=$ Standard length, $\mathrm{PCL}=$ Pre-caudal length, $\mathrm{HL}=$ Head length, $\mathrm{BD}=$ Body depth, $\mathrm{ED}=$ Eye diameter $\mathrm{TL}=$ Total length

Analysis depicted a strong homogeneity of regression on different body parts on total length between male and female fish and it was found non significant (Table 1, 2). This revealed that statistically there was no difference in growth rates of different morphometric characters. 


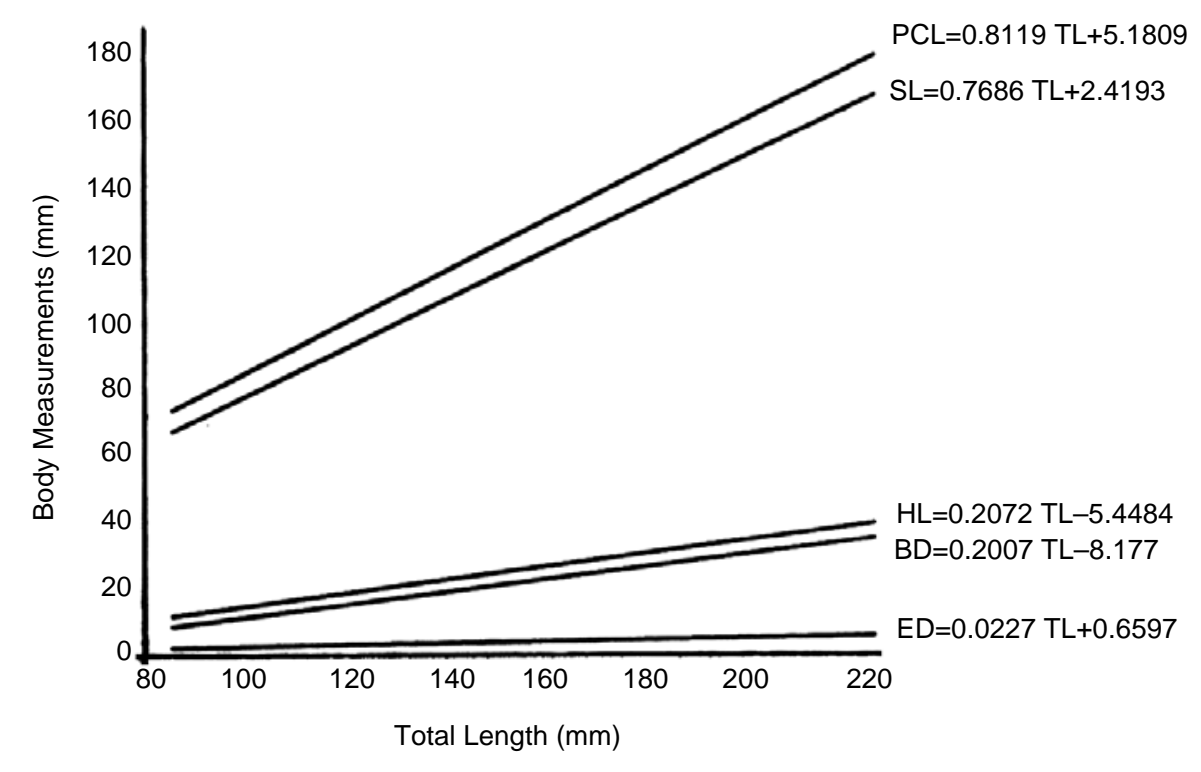

Fig. 1. Relative growth of body measurements on TL (pool) of estuarine catfish Mystus gulio

The length weight relationship of males and females were not significantly different. The regression equation is expressed as-

$\begin{array}{ll}\log W(\text { Female) } & =-69.301+0.7145 \mathrm{TL} \\ \log W(\text { Male) } & =-44.108+0.5229 \mathrm{TL} \\ \log W(\text { Pool) } & =-55.808+0.6203 \mathrm{TL}\end{array}$

Different morphometric characters of male and female $M$. gulio indicated that percentage growth value of SL, BD and HL were higher in female whereas the growth percentage value of ED is lower in male. Thus it may be inferred that female shows slightly faster linear growth of the above mentioned body parts than the males in $M$. gulio. These values of growth percentage of different morphometric characters on total length showed heterogeneity though they were statistically not significant. This heterogeneity of morphometric characters may be due to difference in physiological activities in the male and female fish. Such phenomenon has been reported by Khumar and Siddiqui (1991) in Puntius sarana.

In the present investigation, morphometric characters under taken for the growth in relation to the total length of the fish indicated a linear relationship. The linear relationship of various morphometric characters and total length have been reported by Chatterjee et al. (1977), Tariq et al. (1977), Khumar and Siddiqui (1991) and Tiwari and Qureshi (2003). The nonlinear relationships between various morphometric characters and total length of the fish have been reported by different investigators (Godsil, 1948; Marr, 1955). According to them the ratio in different morphometric characters with increase in length at different stage of life may not be having constant relative growth. Pritichard (1931) and Tandon (1962) stated that there were different ratios between different morphometric characters and total length of males and females in the fish species studied by them. Thus, unlike those fish species studied by Pritichard (1931), Godsil (1948), Marr (1955) and Tandon (1962), different body parts of $M$. gulio are dependent variables on total length of the fish and are having proportionate growth. 
The exponential values of length weight relationship between males (0.5229) and females $(0.7145)$ indicated slight variation. However, these values were significantly different $(p \leq 0.05)$ between sexes. Tiwari and Qureshi (2003) stated that, the exponential values of length weight relationship between males and females in case of Rita pavimentata was around 3. These values in males and females did not significantly deviate from the cube law, indicating isometric growth pattern, maintaining specific body shape throughout their life.

The higher values of $r$ showed that the variables are highly correlated. Hoque (1984) stated that the variables of FL, Pect. FL, PCL, FL, DFL, AFL and HL were highly correlated with TL, while ED and POHL were highly correlated with $\mathrm{HL}$ in Harpadon nehereus. Similar findings have also been reported by Ganguly et al. (1959), Chunder (1977) and Prakash and Varma (1982) in the fishes studied by them. Growths of various variables in relation to total length are presented in Table 1. Literature available regarding the growth rate of the various variables in relation to the total length indicates that the growths of various morphological body parts vary from species to species in fishes. In the case of Ophicephalus gachua, Mehta and Bapati (1977) stated that the growth rate of the standard length and the height of the body increased with the increase of total length, while the growth of interorbital width and snout length remained constant throughout the period of observation. In Harpadon nehereus, Hoque (1984) stated that the growth rate of variables, like the length of anal fin and eye diameter, showed no definite change, while the growth rate of variables like the length of pectoral fin, pelvic fin and dorsal fin decrease with the increase in total length. On the other hand, the growth rate of post orbital head length decreases first with the increase in total length and later increases as the total length increases. In case of red tilapia (mutant Oreochromis mossambicus $\mathrm{x}$ Oreochromis niloticus) the growth rate of variables like standard length, pelvic fin length, pectoral fin length, anal fin length, eye diameter and interorbital width shows no definite change. But the growth rate of body depth gradually increases with the increase of total length. On the other hand the head length decreases with the increase in total length up to $150 \mathrm{~mm}$ and then gradually increases with the increase in total length (Kohinoor et al. 1995). Tiwari and Qureshi (2003) stated that, in case of Rita pavimentata percentage growth value of $\mathrm{FL}, \mathrm{SL}, \mathrm{PCL}, \mathrm{BD}$ and $\mathrm{HL}$ were higher in male and thus inferred that male shows slightly faster linear growth of above mentioned body parts than females. Different morphometric character showed heterogeneity due to difference in physiological activities in the male and female fish.

There was sexual dimorphism in $M$. gulio, which was distinct and prominent during breeding season. In the male a muscular papilla with dark red tip is prominent. Presence of genital papilla in the males of various catfish species has been noticed. Mookherjee et al. (1941) in Macrones gulio (Ham.) and David (1963) in M. gulio described this papilla and reported sexual dimorphism in them. Hora and Law (1941) reported sexual diamorphism in Gagata spp. and Batasio spp. Mukherji (1936) described genital papilla in Glyptosternum reticulam.

\section{Conclusions}

M. gulio showed isometric growth pattern and other morphometric characters studied were proportionate to the total length. The fish exhibited sexual diamorphism.

\section{References}

Alam M.J., Begum M., Islam M.A. and Pal H.K. 2006a. Induced spawning and fry production of nona tengra Mystus gulio (Hami.). Progress. Agric. 17(1): 235-238. 
Alam M.J., Begum M., Islam M.A. and Pal H.K. 2006b. Spawning behaviour and induced breeding of an estuarine catfish, Mystus gulio (Ham.). Bangladesh J. Fish. Res. 10(2): 101-109.

Begum M., Alam M.J., Islam M.A. and Pal H.K. 2007. On the food and feeding habit of an estuarine catfish Mystus gulio (Hamilton.) in the South-west coast of Bangladesh. Univ. J. of Zool. Vol. 26.

Carlander K.D. and Smith L.L. 1954. Some factor to consider in choice between standard, fork or total length in fishery investigations. Copeia, 3: 7-12.

Chatterjee A., Siddiqui A.Q. and Khan A.A. 1977. Morphometric studies on Labeo bata (Ham.) from the different freshwater environments. Indian J. Ani. Res., 11(1): 47-49.

Chunder S.L. 1977. Morphometric characters and their relationship in Gudusia chapra (Ham.) Proc. Ind. Acad. Sci. B., 80(2): 57-67.

David A. 1963. Sexual dimorphism, fecundity and food of the estuarine bagrid, Mystus gulio (Ham.). Proc. Nat. Acad. Sci. India, 33(B): 385-410.

Day F. 1989. The fauna of British India, including Ceylon and Burma; Fishes 1. Taylor and Francis, London. 287 p.

Ganguly D.N., Mitra, B. and Bhattacharya, A. 1959. On the inter relationship between the total length, standard length, depth and weight of Lates calcarifer. Proc. Nat. Inst. Sci. India. 25: 158-175.

Godsil H.C. 1948. A preliminary population study of the yellow fin tuna and the albacore, Calif. Fish \& Game. 70: 9091.

Hile R. 1948. Standardization of methods expressing length and weight of fish. Trans. Amer. Fish. Soc., 75: 157-164.

Hoque B. 1984. Morphometric characters and their relationship in Bombay duck, Harpadon nehereus (Hamilton). Bangladesh J. Zool., 2: 105-108.

Hora S.L. and Law N.C. 1941. The fresh water fish of Travanncore. Rec. Indian Mus., 43: 254-255.

Khumar F. and Siddiqui M.S. 1991. Length weight relationship of the carp Puntius sarana (Ham.) of a reservoir and three reverine ecosystems in North India. J. Freshwater Biol., 3(1): 81-88.

Kohinoor A.H.M., Shah N.C. Akhteruzzaman M., Shah M.S. and Mahata S.C. 1995. Morphometric characters and their relationship in red tilapia (mutant Oreochromis mossambicus x Oreochromis niloticus). Bangladesh J. Fish., 15-18(1-2): 19-24.

Le Cren E.D. 1951. The length-weight relationship and seasonal cycle in gonad weight and condition in perch (Perca fluviatilis). J. Anim. Ecol., 20: 201-219.

Marr A.C. 1955. The use of morphometric data in systematic and relative growth studies in fishes. Copiea. 13: 23-41.

Mehta D.P. and Bapati S.S. 1977. Statistical relationship in between body measurements of Ophicephalus gachua (Hamilton-Buchanan). Marthwada Univ. J. Sci., 16(9): 74-77.

Mookherjee H.K., Mazumdar S.R. and Dasgupta B. 1941. Sexual diamorphism in Macrones gulio (Ham.). Indian J. Vet. Sci., 10(3): 295.

Mukherji D.D. 1936. Report on fishes, Part II, Sisoridae and Cyprinidae. Mem. Conn. Acad. Arts. Sci., 10: 328-329.

Prakash M. and Varma B.R. 1982. Morphometric characters and their relationship in Notopterus notopterus (Pallas). Bangladesh J. Zool., 10(1): 14-21.

Pritichard A.L. 1931. Toxonomic and life history studies of the ciscoes of lake Ontario. Univ. Toranto stud. Publ. Ont. Fish. Lab., 44: 1-78.

Snedecor, G.W. 1956. Statistical methods. The lowa college press, Ames, lowa, U.S.A., 534 p.

Tandon K.K. 1962. Biology and fishery of Chooparai selaroides leptolepsis (C and V). Indian J. Fish., 8: 127-144.

Tarique H., Khan A.A. and Chatterjee A. 1977. Sexual diamorphism in the morphometric characters of a carp, Labeo calbasu (Ham.). J. Zool. Res. 1(2): 90-92.

Tiwari V.K. and Qureshi T.A. 2003. Morphometric characters of the catfish, Rita pavimentata (Gunther) from the river Narmada. J. Inland Fish. Soc. India. 35(1): 68-72. 